\title{
CRITICAL ANALYSIS OF THE IMPLICATIONS OF NEW MANAGERIALISM ON ETHICAL, DEMOCRATIC AND PROFESSIONAL VALUES IN PUBLIC SERVICE
}

\author{
Jose G. Vargas-Hernández \\ University center for economic and Managerial sciences, University of Guadalajara \\ - México
}

\begin{abstract}
This paper aims to critically analyze the implications of the new managerialism in the public service through ethical, democratic and professional values. It assumes the contradictions between the values that seek to promote the public service under the model of managerialism and the reality of its implementation. The method used is analytical-descriptive-normative from the critical perspective of the parallel developments of managerialism and public service. The theoretical and methodological framework that serves as a reference for this critical analysis is provided by the theories of organizational economics and public choice. The discussion concludes that there is a necessary conflict between ethical, democratic and professional values of these new organizational forms promoted by managerialism through the theories of economics and organizational public choice and traditional values of public service.
\end{abstract}

Keywords: organizational economics, public choice, managerialism, public service, values.

Resumen: Este trabajo se propone analizar críticamente las implicaciones que tiene el nuevo gerencialismo en el servicio público a través de los valores éticos, democráticos y profesionales. Se parte del supuesto de las contradicciones existentes entre los valores que el servicio público intenta promover bajo el modelo del gerencialismo y la realidad de su implementación. El método empleado es el analítico-descriptivo-normativo desde la perspectiva crítica de los desarrollos paralelos del gerencialismo y el servicio público. El marco teórico- metodológico que sirve como referencia para este análisis crítico es el proporcionado por las teorías de la economía organizacional y la elección pública. La discusión concluye en que hay un necesario conflicto entre los valores éticos, democráticos y profesionales de estas nuevas formas organizacionales promovidas por el gerencialismo a través de las teorías de la economía organizacional y la elección pública y los valores tradicionales de servicios públicos.

Palabras clave: Economía organizacional, elección pública, gerencialismo, servicio público, valores

\section{Introduction: The new managerialism}

The new managerialism in the public sector organizations is a management perspective with approaches to public administration it reveals that at least has elements in common. The prospect of public administration is influenced by ideology or managerialism as is popularly known as term. Occupational identity of bureaucratic and professional management has been affected in some way by the differential effects of managerialism in contemporary organizations. Managerialism has been used in numerous ways in the literature of public administration and its origin is an open debate though the term is closely associated with the book of James Burnham (1941) dealing revolution administration. However, it is uncertain that Burnham has used this term. Outside the mysterious origin of the term, the question that immediately comes to mind is what managerialism is. 
The reform of the administrative bureaucratic state apparatus is oriented in the new managerialism; processes of democratization and to consumers in competitive markets make rational choices, which end up reducing the citizen into a consumer. The new managerialism incorporates business sector management tools and practices that separate the administrative functions of policy, the exclusive activities of the State and other economic agents and political actors, introduced the methodology of process reengineering, systems tied to performance incentives and forms of accountability.

The British academic Chistophe Pollitt (1990) has given this matter considerable study and analysis and has done some valuable work that is especially instructive to make a critique of managerialism and its influence on British and American utilities and public services. Pollitt (1990) constructs an intriguing story about the managerialism that needs to be understood as an ideology with some concrete and immediate consequences.

\section{Conceptual framework: Theories of organizational economics and public choice.}

Besides the emphasis on rational choice theory and traditional theories of organizational psychology organizational analysis still the organizational analysis ignore much about action and organizational life (BURRELL and MORGAN, 1979, Denhardt, 1981, Harmon and Mayer, 1986, White and McSwain, 1990, Bailey, 1992). On the theory and practice in public administration the inter-organizational issues relate to the implementation of policies consistent with the theme of the analytic practice that evaluates the applications of rational choice, specifically the theory of games.

The New Economic Policy that gives support managerialism avoids holism of orthodox economics to appreciate social phenomena in institutions, such as corporate culture, etc., to perform policy analysis by comparative institutional analysis. The two pillars of orthodox economics are neoclassical theory of the firm and the neoclassical theory of consumer behavior. The neoclassical theory of the firm as a production function is a technological construction in which the inner workings of the company, shapes and internal arrangements of the organization and in relation to the market are analyzed. That is, not only the internal phenomena of the organization but also in contractual relationships with other companies are analyzed.

The economic agents make transactions by using contracts and standardized rules for economies of scale; reduce transaction costs and greater efficiency in international operations procedures. Criticism of orthodox economics are, among others, that their focus is on the collective rather than individual action, there are more evolutionary preference for a more mechanical approach to the economy and an emphasis on empirical observation rather than the deductive reasoning (KLEIN, 1998).

This kind of conceptual and methodological trans disciplinary approach becomes more necessary by the limitations of existing theoretical framework have, such as the neoclassical economics theory, the Frankfurt School, evolutionary economics and the so-called critical realism. Moreover, institutional theory has been criticized for giving more importance to the explanations of the culture of 
those of power and market competition. The institutions are located in cultures, social structures and routines. Cultures are performing structures, patterns of meaning and systems of rules. Social structures are expectations that are tied to social networks, systems of formal roles and positions.

In the new institutional economics, political aspects limit the benefits of trade, such as in the specific situations of asymmetrical negotiations because it prevail vested interests that create distributive conflicts. Institutional economics studies the economics of transaction costs, the economics of property rights, the principal agent theory, approaches to constitutional economics and public choice.

The economy of the organization focuses on the coordination and transaction costs of economic activity, under the argument that under conditions of perfect competition, these costs are zero to use the market as a way of allocating resources, in the assumption that the required information is complete. The economy of the organization proposes that organizations matter and that they are amenable to analysis.

The neoclassical view of how markets behave and how institutions should act is based on the rational choice theory organizational economy. The rational choice theory holds in the hypothesis that choice behavior of individuals try to maximize their own levels of satisfaction, hypothesis cannot fully affirmed. Under the approach of rational choice proposed by institutionalism, institutions must be designed so as to maximize the rationality of individuals, to maximize the achievement of benefits and to reduce transaction costs of its shares subject to market relations.

The organizational economy is characterized by coexistence in a constant state of creative tension between vigorous but intensive market competition and multiple companies. In a stronger competition more competitive market structures are generated. In a competitive model, organizations maximize their benefits if they have a technology to generate constant returns to scale. The continuous interaction between companies subjected to a relentless search for new ways to create value and markets, pressure companies to pay part of this value to others. The new institutional arrangements that give rise to new forms of governance provide benefits far outweigh the investments that meet contractual relations, according to the agency theory, between the principal and the agent, through a set of organizational and institutional rules so that determine rights and obligations of employees and reduce opportunistic behavior to a minimum.

The main problem with economic analysis of the organization is the problem of adaptation and for that develops the concept of collaborative adaptation as a conscious, deliberate form and purposeful work by the administration. Adaptation involves lower transaction costs and higher outcomes of change than reform. The logic of autonomous and cooperative adaptation leads to a predictive theory of organizational economics (BARNARD, 1938, p.4; WILLIAMSON, 2000, pp.8-9).

In the theory of the collective decisions of Coleman (1988) micro and macro social are integrated on the basis of rational choice theory considering social capital as resources of the actors in the form of obligations and expectations, information flowability of social structure and sanctions of regulations. The rational choice theory, according to Coleman, is one in which each player has control over 
certain resources and interests in certain interests and events. The existence of at least two actors and control of resources is the basis of the social system.

The new managerialism sustains the approach of the administrative liberation and management focused on the market through the public choice. It is argued that those who promote the administration to release market-oriented and conservatively accept behavioral assumptions and principles that underpin the public choice and organizational economic theory to all intents and purposes in administration.

In turn, the design of the neoliberal state and the formulation of public policies are oriented and conformed to the fundamentals of rational choice and public choice theories of neoclassical economics. The principles underpinning the design of State defined the characterization of its formalistic bureaucratic structures, decision making processes highly hierarchical and centralized public decisions, obsession with the pursuit of operational rationality, that homologates administrative procedures and depersonalize or treat equally citizens, the desperate search for quality of processes which increase the delivery of public goods and services unless there are corresponding benefits, etc.

The public choice theory explains the economic and political behavior in function of the search maximizing the benefits of individuals performing different interactions in an institutional context which achieves certain balance between the main economic agents and actors who perform trading strategies, competition, forming alliances and coalitions, etc. This conception of public choice has resulted in market fundamentalism that believes that all human interactions are reducible to simple market transactions. March and Olsen (1995) criticize this approach arguing that exchanges occur between unequal players in power so they are not always free and seek to maximize the utility, the political system based on economic exchange has pernicious moral effects that weaken the balance of the democratic governance as a result of encouraging selfish benefit.

The authors argue that if human nature is fluid result of a process of social evolution, the design of political institutions cannot begin with an unshakeable human nature, but of the responsibility for building institutions that encourage positive trend towards better balance between self-interest and the public interest. Set human nature in the purely commercial model is not only an alibi for the defense of the status quo but a renunciation of human progress, which has no historical foundation.

According to this design approach of the state, individuals seek to maximize their profits. The public choice is related to the analysis of modern state administration represented by the performance of administrators and public servants pursuing profit maximization. States that promote this kind of "internal market" trading transactions are made between different departments together, and if they find a better deal out of its structure, they make it.

The new managerialism supports liberalization management and administration market oriented which consists of a complex mixture of public choice and organizational economy theories, with agency theory and transaction costs economy. Theories of organizational economics and public choice are directly involved with an orientation of methodological individualism because it focuses on the self-interest above any reasoning rejecting the concepts of public interest and public good and grants and intellectual little moment. 
The new managerialism is based on conservative consecutive shifts in public choice and organizational economics comprising the agency theory and the economics of transaction costs. The direct exercise of authority is costly in terms of transaction costs to specify, monitor and strengthen management; organizations typically delegate discretion to its members as a way to reduce costs. Theories of organizational economics and public choice as assumptions assume that public managers are inclined naturally and predisposed to be cheaters, liars, and to engage others in opportunistic behavior, because they seek their own benefit.

The public choice and organizational economics share many of their values and basic assumptions that are based on the argument that human beings are rational economic actors who seek to maximize their own profits and are guided by a competitive self-interest. The theory of organizational economics tries to determine the old idea that the economy efficiency and effectiveness should be priorities for the government. Pollitt (1990) claims that managerialism is a set of beliefs, values and ideas about and related to the state in the world and how it should be.

In high performing organizations, people have and keep values that work as guides or guidelines for carrying out their activities efficiently in an environment that is changing. The study of the role that values have in improving organizational performance has not received the attention of the administrators. It should assess organizational performance but also if organizations are good places to work, either to nurture public service values and a spirit of dedication to the public good.

The State has promoted the market and has not supplanted it, it has promoted the coordination of private interests, so the development of a theory that supports these important contributions to the development of the state, would be more complete if it goes beyond the ends of the principles of Marxist development who focuses all the importance in the state and the public choice that considers the state as a predator or annuitant.

The survival of the regulations may have as an explanation the theories of public choice about groups and rent-seeking. Thus, the policies developed outside this definition of neoclassical State are seen as generators of economic rents to support the payment of corruption (bribes) and to reward voters for political support. Therefore, economic rationality has forced the nation-state to dismantle institutions and regulatory bodies in an attempt to achieve the ideal concept.

The concept of a government by the people leads us to precepts and theories of participation, majority, representation, civic republicanism, public choice and even financial campaign. The majoritarian model is not a problem for democracy but a consequence of it. Majoritarian institutions suffering from the burdens of the processes have no reason to complain when misuse of power agreed by the system of majority rule, but it seems that majority rule is itself undemocratic, so that decisions via electoral majorities are not necessarily the way for good governance, which is developed through mechanisms that allow society to its economic development.

The challenge is to identify, define and implement some sort of obligation on the government to those who are not part of the majority. 


\section{Method.}

The method used is the normative-descriptive-analytic from the critical perspective of ethical, democratic and professional values as parallel developments of managerialism and public service. The theoretical and methodological framework that serves as a reference for this critical analysis of ethical, democratic and professional values is provided by theories of organizational economics and public choice.

\section{The public service}

A public administration geared to serve the public, the group as a source of performance forces to rethink and redesign its functions and processes in new forms of organization that promote transparency and accountability and take into account the views of citizens involved in the processes of decision making, formulation and implementation of public policies. Under the assumption of "sequencing", to enter the new management reform that promotes greater flexibility in public employment, it was necessary to have completely covered the stage of public services involving the civil service in the career managers.

The establishment of a system of career civil service contributes to develop more qualified professionals and trained administrators seeking to make more efficient the public administration and to provide continuity in their programs. A public service of higher quality, effectiveness and stability is supported by a system of civil service that renders more professionalism and gives greater coherence to the continuity of programs of governance, despite electoral changes and thus the ideological positions. Therefore, the processes of government are subtracted from the political maneuvering that only serves to get the benefits of groups and political factions at the expense of collective benefit.

Public service issues have been analyzed with the principles of democratic life and it is looked at three major issues, the convention surrounding public service anonymity, issues of accountability arising from new forms of organization and delivery of government programs and services, and questions about the congruence between political values and public service. Public service organizations differ from other organizations in that all its actions are taken into account by the requirements of the particular brand of democracy. Here are some key features of organizations pursuing a mission of public service contracts.

Other components of such a regime that may be considered for inclusion are as follows: Evaluation of ethical performance as the basis for naming and promote all members of the public service but especially its leadership. In a collective sense, administrative organizations are exercising the formative influences. This is a failure to provide leadership in the context of the professional institution considering that the public service is more than a bureaucratic organization in this critical issue. As part of a major mission of an organization whose purpose is to preserve the natural heritage of a nation, the provision of public services such as the case of parking lots, may be the main organizational vehicle, mostly when it comes at a high level of generality. 
It is difficult to resolve problems of jurisdictional conflicts between public service agencies simply distinguishing between core and thus the periphery, either on the basis of the hierarchical ordering of offices or organizations or on the basis of a distinction between the responsibilities for policy and operations. It is illustrated by the fact that many utility functions have the biggest impact on organizations regarding the use of state authority that are held by those on the front lines of the profession of public service. This is the proverbial street-level bureaucrat to deliver public services and make enforceable regulations.

The public management approach has emphasized the importance of managing bottom up paying close attention to the quality of organizational life and performance of the service quality. There is a need for sustained attention to the state of public service ethics, what is needed is ethical by choice rather than eventuality.

The public service code of the United Kingdom for example, speaks of the obligation of public servants to assist governments duly elected and constituted with integrity, honesty, impartiality and objectivity and to recognize its accountability to the minister. Code UK services effective on the nineties began with the assertion that the constitutional and practical role of the civil service was to assist the duly constituted government in the formulation of government policies and carry out government decisions and administer public services. Similarly, the Public Service Code of New Zealand provides early in extensive terms that the first priority for public servants is to carry out terms of government policies.

It is argued that public servants should serve the interests of the wider community of those interests that are determined by the duly elected governments.

\section{The public service values}

The normative rationality shows a movement of the organization to the institution, which legitimize the organizational elections in reference to the mission and values of the organization holding the organizational integrity. In a democratic system, public servants need to be constantly reminded that they are not politicians elected but appointed public servants whose values should determine what is in the public interest.

The government runs in function of values based on the market, efficiency, performance, initiative, flexibility, risk-taking, rewards, rather than the traditional values of the administration such as prudence, stability, equity, etc. The public service values are observed only to the extent that all those involved in defining public service functions, as opposed to simply providing organizations with various types of goods and services, are themselves as belonging to the profession of public service.

It is recognized that public service values are invariably subject to the informal dynamics of organizational behavior or office politics and that these dynamics, in time influence on the adherence to public service management as a profession. 


\section{A. Principles and values}

The New Public Management (NPM) is aimed at changing institutional structures in transition to norms and values that differ from changing strategies of individual actors. A quality governance encourages social synergy aimed at increasing services to society through profound changes in the institutional structures of government and the establishment of conditions such as the establishment of a society with an atmosphere of legality, civility and compliance law, constantly updating regulations of public administration to adapt to the changing environment and values, of social movements and new political, social demands, trends in participation and civic-citizenship co-responsibility, etc.

The social and institutional capital sustains the values, norms and arrangements between the different economic agents and political and social actors. The terms of values and principles are often used interchangeably to aid in the development of a code of conduct for business, consider the principles and basic standards of personal conduct that can be used to connect large values to specific rules. The grand volume of material that is contained in the literature focused on the reference to values, and that is used for the analysis of organizations, allows understand more clearly the central significance that have certain values.

From the point of view of defending the integrative uniformity and integrity of society and nation state to promote common causes and on the basis of a community of fundamental values and standards of the groups that make up society allows expression of the plurality of society and whose goal is aimed at the abolition of cultural differences. Integrationists claim that all members of the groups settled in a territory forming a community by internalizing values and compliance, while recognizing the right of minorities to express their own culture in the interchangeable domains of public and private.

A dense associationism in a political and economic environment that fosters respect for the values and interests of all stakeholders, are the basic conditions of a democratic liberal system. The activities of civil society consolidate democracy from associationist forms defined by liberal values. The center of the values contained in a code of conduct should leave the three categories of values that need to be included: ethical values, democratic values and professional values.

\section{B. Ethical values}

Ethical values can usually be seen as a source of which the principles and rules are derived. The commitment to share ethical values is likely to be strengthened by enshrining in a formal document egg a code of conduct, code of ethics or a values statement. If there is a statement of values, including ethical values, either as part of a strategic plan or as a separate document, it should therefore be a code of ethics or conduct linked to the value statement that sets out the general principles of ethical conduct.

A potentially valuable component of the framework of public servants is a code of conduct where in addition any of the rules for public service ethics must be firmly rooted in the ethical values so that public servants understand the underpinnings of these rules. The ethical content of a code of conduct should consider the behavior of public servants must be based on a clear statement of the 
fundamental ethical obligations of public servants. These obligations can be expressed in terms of fundamental, core values and principles underpinning the rules of conduct and ethical values.

For example, the ethical values of integrity and justice underline the principle that public servants should not use their public office for personal gain. This principle in turn underlines detailed rules as those providing that public servants should not seek personal services by receiving personal treatment. The emphasis on this obligation alerts the public servants of the importance of its rendering of latest accounts to the political, the critical consideration of all citizens in all political systems executive. As it can be provided a solid foundation for ethical discourse and ethical action it is only one part of a comprehensive ethics regime. Similarly, detailed anti-discrimination rules derived from the principle that public servants should treat all citizens fairly, a principle that is based on ethical values such as respect and justice.

It has been argued the importance of examining the ethical content of the public service code of conduct and the relationship between ethical values, principles and rules. Beyond a broad code of conduct of public service, or declaration of principles which establish the values that are inherent in the concept of public service is a means of aid but not enough to promote and strengthen public behavior. There must be discussed recent events with an important ethical dimension and the implications for public service ethic of public service reforms and they have to delineate the possible components of a framework to encourage and preserve ethical conduct. In Britain, the committee on standards in public life Nolan supported a code of conduct for public service and ethics training as a means to restore respect for the ethical values inherent in the idea of public service.

The communities that share ethical values are the most effective organizational forms, so the people who form them may be the most effective without renouncing its community. Social policy must be based on ethical values that define the objectives of development, economic rationality that underlies them and the means and capabilities to their achievement.

\section{Democratic values}

Economic globalization and economic openness is related to the practices of a capitalist economy based on market liberalization while political globalization refers to the practice of democratic values. The neoliberal model of development with its strategy favoring capitalists, stimulates the formation and operation of a motivated civil society in democratic values that opposes the authoritarian state decisions, reduce its functions to give more scope to the free market. While promoting democratic values, most advanced capitalist nations support dictatorships of the client States that repress democratic movements to benefit their companies and products.

A code of conduct should include a reference to two or more types of securities. The first of these values are democratic values, among which are considered for example, commitment to the public interest, loyalty to the current government, respect for the law and democratic accountability. It is significant that some democratic values also have substantial ethical content. Therefore, the importance of certain values is motivated by the fact that both are ethical and 
democratic values. Among the main values that relates to democracy are the values of accountability, transparency, responsibility and openness.

Most of the values, for example, accountability tend to complement loyalty, but with some of them, for example, customer service has occasionally crashes. Such as loyalty, several values such as accountability, integrity, etc., are critical values that belong to what is right or wrong.

\section{1) Customer service}

The theory of government and new public administration focuses on the people considered as customers to be served rather than as citizens with interest to be projected. The adaptation of the term client as consumer has helped revitalize the public service motivating managers to find what service recipients really want and need. Besides the term customer service facilitates measuring results and values to customers, identify and target processes that support service delivery, considering they may have internal customers also in their own organizations or elsewhere in the public service.

\section{2) Loyalty to the current government}

The governance of the society is at risk of informalisation processes of democratic politics that have modified the bonds of loyalty between the state and citizens. Representative democracy institutionalized in the social state of rule of law meets the requirements of ethics that becomes inexcusable the loyalty makers. Internal moral incentives are less effective in organizations because decisions are made in the groups influenced by orders or other groups, which deadens the sense of personal responsibility, in addition that the organizations set their own standards of loyalty. Individuals change their decision-making criteria of long-term factors, such as group loyalty and affection to the parties, by short-term considerations of policy preferences and performance evaluations.

Ministers, MPs and all public servants have a duty of loyalty to the duly elected governments. The government does not have a code of comparable public service behavior, but it has several official statements containing different coded messages in languages such as ministers who are supported in exercising their responsibilities for public service and whose duties are to give non-partisan loyalty and support for the government of the day. Therefore, despite the importance of loyalty value, careful count should be taken from other values.

Public servants accept loyalty to properly present elected government as one of several traditional values including citizen service, honesty, integrity and commitment to merit and justice. Therefore, loyalty to the current local government is a primary ethical obligation for public servants, an obligation that is often specified in codes of conduct and other official documents that describe the roles and responsibilities of public servants.

\section{3) Accountability}

On the political side, advances in democracy, transparency and accountability of government institutions are mentioned. The democratization of the state and New Public Management are processes that are interrelated and are suitable depending on the different situations of national states. The idea of a government of the people refers to the provision of the accountability of 
government actors. Governance (governance) is a product comprised of intra and inters networks involving the phenomena of co-management and co-management under mechanisms of accountability, transparency and accountability implemented by designing inclusive governance structures and supervised by the government. Social control is a tool for greater accountability practices that are incompatible with the heritage.

The societal accountability is defined O'Donnell (1999) as a vertical "no electoral mechanism, but political authorities control that rests on the actions of a multiple set of citizens associations and movements and the media, action which aims to expose governmental mistakes, bringing new issues to the public agenda, or activating the operation of horizontal agencies. The author distinguishes two directions of horizontal accountability, illegal violation by a state agency of the authority of another and corruption that are unlawful advantages that officials receive for themselves and / or their partners. The effects of stimulation of horizontal accountability and societal accountability induction vertically are important for understanding the dynamics of democratic politics.

The effects found in the interactions of the different types of accountability are the most important. Therefore, it is necessary to identify rules, enforcement mechanisms or standards of behavior from becoming costly disabling or the use of discretionary power by the sovereign (Nahallel, 2000). O'Donnell (1999) defines horizontal accountability. The existence of state agencies that have legal authority and are factually willing and able (empowered) to take actions ranging from routine checkup even criminal sanctions or impeachment in relation to actions or omissions by other agents or state agencies that can, in principle or presumably be classified as illegal.

The horizontal accountability balance is exercised by the executive, legislative or judicial powers in adherence to constitutional provisions. The accountability is assigned to be made through agencies created for effective monitoring, prevention and punishment proactively and continued illegal acts or omissions of other state agencies. Accountability is bottom-up to the members of the organization and top-down into a system of participatory democracy and stakeholders and consumers. The accountability of the local government is done in the internal, external, state and national levels, in society and other donors, financial institutions and credit agencies, etc.

Management of local systems can lead to greater institutional efficiency, transparency and accountability in the development and delivery of social services. Decentralization processes considered as strategy practices of NPM with neoliberal orientation adapted bureaucratic administration to the demands of citizens, increase political participation and employment of mechanisms of social control and accountability.

These processes of accountability involve traditional forms of accountability such as audits, procedural rules, parliamentary review and new forms such as social control, management and competency contracts. An instrument of the civil society to build a culture of accountability is the inclusion of mechanisms for monitoring and social audit. The social audit should implement the state and society integrated by component of users and social groups through agents responsible for a chain of control that begins with the formulation and beyond by implementing mechanisms of accountability requirement that are from the state. 
The implementation of a more efficient public administration management system that promotes accountability, assumes the existence of a democratic system with well-established rules of law. Structural inequalities remain untouched and the lack of means to monitor the impact and collective accountability to perform new tasks. Power and accountability for its use were laid by the owners for control by the senior management of traditional bureaucratic organizations, it has become a more complex issue in organizations where there is a multiplicity of shareholders and whose form of organization is more horizontal. The recovery of power by society is to give democratic processes a sense of democratic governance that gives the citizen participation in decision making and in demanding accountability from the authorities.

It is argued that the biggest problem of democratic accountability in the new approach is that it is a changing relationship between elected officials who have a top-down authority over public bureaucracies and administrators in the new public management. However, one of the biggest problems of the NPM is to maintain and administer the bottom up control of all officers and officials, those appointed or hired through temporary contracts for the provision of services as well as those selected for final and definitive recruitment.

Public sector organizations, traditional departments or new agencies must respect the most important values that are enforceable accountability for them. Because the internal accountability of the public service is closely connected to good governance, the agency responsible for surveillance should be used to advise the government on key issues of public service and public administration on the basis on which are being implemented.

With regard to accountability and new organizational forms, an example of the new environment for public service values is the advent of alternative organizational models to deliver programs and services, such as distinctive services or delivery schedules agencies. For example, Hage and Finsterbusch (1987) identify four basic organizational models and then two more in their work to improve bureaucratic performance in developing countries. In fact, some research suggestions of accountability can be significantly reinforced by such organizational arrangements.

The entrepreneurial model in the new public management is problematic when it is implemented because it supports with persuasive arguments to try to prove the issue of democratic accountability. From the perspective of the new public management controls can be increased to improve the accountability of the delivery of goods and services to citizens of a given community.

The executive model of accountability of public organization must be clear lines of authority and accountability (Moe and Gilmour, 1995). It can help to ensure that organizational designs and management practices work for clarity and precision in the accountability of public service. Accountability of public officials should be held accountable for their actions, which involves effective accounting and auditing, decentralization, micro level accountability to consumers and the role of NGOs.

A public administration geared to serve the public, the collective as a source of performance forces to rethink and redesign its functions and processes in new forms of organization that promote transparency and accountability and take into account the views of citizens and involved in the processes of decision making and 
formulation and implementation of public policies. In the political dimension, the government cannot delegate accountability as it does with the provision of services because it must respond directly or indirectly as the public authority. The government can delegate the provision of services but cannot delegate accountability

For the governance to be effective, it must be considered as requirements setting goals, conflict resolution and different games sum to zero, adjustable process, distinct act, and accountability. So, democracy is an institutionalized value that does not meet the expectations of citizenship which is encouraged by the receptiveness to the demands of the voters, accountability and the right of voters to dismiss elected officials (Sartori, 1999).

4) Integrity and organizational synergy

Integrity and organizational synergy have a direct relationship with the dilemmas of development of institutions. Relationships of inter-organizational integrity induced by donors and advisers in the field of development have influenced the development of the workers into organizations. However, predatory states create and develop their relationships with business leaders to maintain their own interests with low levels of integrity and organizational synergy.

Weber's thesis of organizational integrity uses the idea of synergy that defines the relationships that connect citizens with public service official bureaucrats. Organizational integrity in the concept of Weber $(1982,1946)$ is associated to formal bureaucracies and the rule of universal right to economic development. At the beginning of last century, Max Weber (Weber, 1978) argued that the purely bureaucratic type of administrative organization managed to achieve the highest degree of efficiency.

Irresponsibility and indifference of organizations to meet the needs of different groups of interests results in very low levels of integrity and organizational synergy. An organizational integrity without having synergy results in low productivity. Excessive bureaucracy in the administrative apparatus of the State and the absence of a vibrant civil society are renters, ineffective and inefficient behavior. For example, a combination of little integrity and organizational synergy contribute little to development results, especially tends to reduce the average standards of quality of life (see Figure 1 ). 
Figure 1. Integrity and organizational dilemmas synergy in top-down development

\begin{tabular}{|l|c|c|c|}
\hline \multirow{4}{*}{$\begin{array}{c}\text { Synergy } \\
\text { State-society } \\
\text { relations }\end{array}$} & \multicolumn{2}{|c|}{$\begin{array}{c}\text { Organizational } \\
\text { capacity }\end{array}$} & \multicolumn{2}{|c|}{ integrity: Coherence and corporate } \\
\cline { 2 - 4 } & Low & $\begin{array}{c}\text { Anarchy } \\
\text { (Failed states) }\end{array}$ & $\begin{array}{c}\text { Inefficiency, } \\
\text { ineffectiveness } \\
\text { (Weak states) }\end{array}$ \\
\cline { 2 - 4 } & High & $\begin{array}{c}\text { Predatory, } \\
\text { corruption, } \\
\text { Failed states } \\
\text { accountability, } \\
\text { Flexibility } \\
\text { (Developing } \\
\text { states) }\end{array}$ \\
\hline
\end{tabular}

The emergence of historical conditions that erode relationships of integration and community development is a function of low levels of integrity and organizational synergy. Predatory states are effective for their ability to conduct their own narrow agendas partly because they hold the monopoly of violence and organizational myopia manifest in little tolerance for dissent.

To preserve any individual characteristic, public administrators must exercise integrity. Public administrators perform the tasks required to defend their agency against attacks, to follow the rules scrupulously to avoid any organizational ineptitude, corruption, debauchery and crime. Similarly, administrators perform tasks to prevent agency resources and authority that can be used for unconstitutional, illegal, forbidden or unsanctioned purposes and even for purposes for which the authorization is patently not explicit. In addition, they acquire special relevance, particularly important organizational skills and political action under the concept of organizational integrity.

Development agencies of international organizations and nongovernmental organizations working to transfer skills and resources to communities need to cultivate integrity and organizational synergy. The changing strategic priorities of organizational activities make the functions and effectiveness of regional development agencies to constitute a requirement to be investigated, examined and monitored. However, regional development agencies are not unified organizations in coherent behavioral roles to emphasize priorities and goals.

\section{5) Trust and social capital formation}

The theoretical and empirical concept of social capital is significant because it is considered a resource that solves static collective action dilemmas groups and organizations. The analysis of the dilemmas of development organizations in the communities allows determining the importance that has the level of social capital. Merton (1957) considered a strategic research site the analysis of the basic dilemmas of development in societies of deprivation, poverty and social exclusion confirming a task from the bottom up and to link up to the economic requirements of social groups. 
The social capital comprises a range of social dimensions to display key attributes for dynamic resolution of dynamic organizational dilemmas by influencing that collective action has in social relations. However, this approach does not solve the considerations on the content of social relations, infrastructure as a means to facilitate the inherent social capital formation. The types of social relationships involving trust and distrust, malice and honesty, order and disorder, are more involved with different forms of social capital with organizational forms. Different combinations of capital are strategically required for the economic development of firms based on arguments supporting the relations between the state and society is inherently zero-sum game strategy.

The social capital model of Portes and Sensenbrenner (1993) identifies the background and effects as well as the positive and negative aspects of conditions and the dynamics of social capital relations within and among particular groups of organizations and communities to facilitate more complex dynamics economic exchanges. The capital is developed in micro and macro levels that integrate different forms.

Figure 2. Forms of social capital development from the top down and bottom up

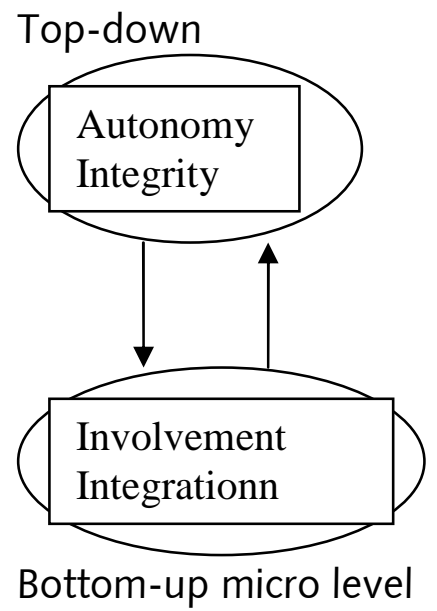

Macro level

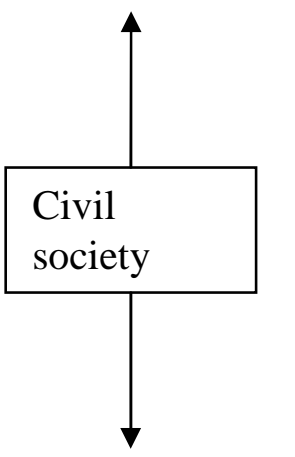

Micro level

A society with high levels of social capital provides access to group members to greater resources and psychological support while transaction costs are reduced. Moreover, a level of negative social capital results in high personal demands to members' restrictions to the free use of community resources, especially through the use of coercive mechanisms that are not from market to the most marginalized groups, without allowing them to move through personal effort.

Social capital as ethnic entrepreneurism, the research of Portes and Sensenbrenner (1993) and Portes (1998) in immigrant communities in the United States conclude that the capital of different groups with different cultural characteristics and phenotypes is high. This situation gives rise to prejudices against these groups which makes to increase confrontations with other groups, decrease the chances of entry and exit and discrimination against them to access greater economic opportunities and rewards. 
Positive social capital formation in organizations and communities also tends to produce other positive qualities in the use of public goods. In organizations and communities where social capital none exists or it is eroded, conflict and discrimination between members of different groups are promoted. These negative aspects are solved or dissipated.

\section{6) Transparency}

The quality of democratic governance depends on the combined action of two elements: First, the nature of state institutions, accountability and transparency of state officials, and on the other, of the nature of civil society and its ability to exercise control over the state apparatus (UNESCO, 1997). Good governance promotes benefits that facilitate citizen participation, maintain political stability, and ensure transparency and the existence of a rule of law that creates trust among citizens (Orozco, 2001).

Latin American countries are in the process of institutional transformation under the premise that the market is the best allocator of resources in the economy and that the functions of the State must achieve greater efficiency, transparency and probity in the use of resources oriented towards promoting economic growth equal opportunities in meeting the social needs and demands, strengthen citizen participation and defense of their rights. However, those who promote these reforms, the international financial institutions, impose globalization processes through undemocratic and non-transparent procedures.

The administrative reform aims to be democratic because it presupposes democratic governance, makes social control by civil society a major form of political accountability, transparency and requires public agencies. In an environment of high competition and enterprise competitiveness, rules become instruments of power that increase the credibility and transparency in global markets, provide guidance, reduce transaction costs where there is limited information and ability to process and create security long-term expectations set by the complex interactions of the agents involved.

With regard to information and transparency, there are three main areas for improvement, information on economic efficiency, transparency as a means of preventing corruption and the public information available for analysis and policy debate (ODA, Overseas Development Administration 1993; World Bank, 1992). Always have to achieve high standards of transparency and due process under the regimes that are subject to allay any fears of favoritism, whether internal or external.

For example, in situations where two or more providers of social services are available, however, the criteria used by organizations and government agencies for the election should be the impact of the election on transparency in the public interest and social welfare. The formative sense as government agencies are mostly related to the results of collective processes rather than individual initiative that has any particular administrator, organizational leader or technical professional.

The answers provide public administration with effective solutions and of quality to social demands they must also be characterized by the public interest and transparency, honesty and transparency solutions, but most efficiently achieve the objectives related to the improvement of social welfare, despite the constraints 
imposed by macro environmental conditions, market dysfunctions and practice of public management techniques.

It is essential that democracy and transparency are also organized at the grassroots level to local levels affected by the interventions of International Financial Institutions. The incorporation of civil society organizations (CSOs) in the formulation and implementation of public policies are established by relationships that are governed by the respect for the independence and autonomy of CSOs, for the recognition of their special identity and transparency and fairness in the treatment according to Martinez Nogueira (2001).

\section{7) Responsibility}

Responsibility is a positive concept that works every day in a quiet, positive way and at all levels of an organization within the public service and to the Secretaries of State. Public managers have a responsibility to lead in articulating their purpose organizations and motivate people to achieve. One element of these special interest organizations that provide for the government is the definition and assignment of responsibilities to executives and other staff in administrative roles. Undoubtedly, individuals in organizations can influence collective processes of formation depending on the nature and extent of how managers define their rules, roles and perspectives they have on their work.

Local levels of government, especially municipal governments have the potential to define the types and categories of activities, goods and administrative services, including traditional with greater responsibility to achieve results (Reichard 1996: 43). The protagonists and actors of local development and their antagonists are involved between local struggles of taxpayers through their respective coalitions and organizations to influence local government policies.

Unfortunately it is not always the case, so that the process of choosing suppliers of public services are provided to many acts of corruption committed by the actors and agents who are responsible for decision-making and other responsibilities. However, this relationship dissipates when different forms of relations between the state and society have an impact on development outcomes based on the combinations of the organizational capacity of the state and its involvement with its responsibility towards civil society.

It is important to move to a more diverse government organizations to have a common understanding of what it means to have counseling responsibilities involving the exercise of public authority in any serving organizational setting. Based on the Westminster model of ministerial responsibility is a central element of the constitution. In addition to the significance of the constitution, loyalty is widely seen as a key ethical value.

\section{Professional values}

With regard to professional values are emphasized some such as excellence, professionalism, fairness and effectiveness. If the public service should be considered professional these values of internal administration should be assumed. Communication, teamwork, respect, trust and discretion, in short, collegiality, are the only signs of a professional organization even when a hierarchy of offices is required by constitutional and administrative purposes. Research conducted by Clarke and Newman (1997) analyzed the occupational identities and professional 
roles of those working in the welfare public sector organizations. The authors emphasize the substantial increase in the number of people working in administrative activities and in hybrid administrative and technical activities.

Communication, teamwork, respect, trust and discretion short and collegiality are the hallmarks of the professional organization. For example, the system of organizational planning is an organized field that involves policy making, decision making processes and professional practices in the spatial-territorial, procedural, cultural, contextual dimensions, relationships and their impact on identities and forms and lifestyles, thoughts, attitudes, etc.

These approaches can be supplemented by other measures that are less common or more controversial than the above, an ethics audit to assess organizational policies and procedures to preserve and nurture ethical behavior, the emergence of ethical considerations in a deliberate and regular basis in meetings and through such other media such as newsletters, the provision of a confidential hotline that public servants can use to discuss concerns about their professional ethical behavior or that of others, including exit interviews, interviews with employees who leave the organization to ask about the views of the employees of the ethical culture of organizations.

\section{1) Excellence}

For example one of the five largest sections of the code of ethics of the American Society for Public Administration is headed to the struggle for excellence. Again it is notable that such values as excellence and professionalism have ethical content.

\section{Conclusions}

It is noted earlier in this paper that public entrepreneurs that promote public service are strongly influenced by the suggestions originated in behavioral public choice and organizational economy. These behavioral assumptions are incomplete and provide a distorted view of the nature of human beings. However, entrepreneurs and public persuasion neo-managerialism only exacerbate problems of application of ethical, democratic and professional principles because the theories involved in the new managerialism are unable to recreate any notion of public interest.

It is required to understand the potential effects of organizational models of public service values and design elements that can support or encourage public service values. Also it is required a review and alignment of all systems management of people to support public service values and reward behavior that promote. Rather it is the State, which benefits from the conduct of public affairs from being more advanced from the core values of public service as they are seen in the organizational forms that are used, including those as open arms of the ministers or state secretaries.

The discussion concludes that there is a necessary conflict between ethical, democratic and professional values of these new organizational forms promoted 
by managerialism through theories of organizational economics and public choice and the traditional values of public service.

\section{References}

Bailey, M. T. (1992). Beyond rationality. Decisionmaking in an interconnected world. In M. T. Bailey and R. T Mayer eds. Public management in an interconnected world. Esays in the Monnobrook tradition. 33-52.

Barnard, Ch. (1938). The functions of the executive. Cambridge: Harvard University Press (Fifteenth printing, 1962).

Burnham, J. (1941). The Managerial Revolution. (Bloomington,Ind.: University of Indiana Press, Midland Books, 1960 reprintedition; originally published 1941).

Burrel, G. And Morgan, G. (1979). Sociological paradigms and organizational analysis. Portsmouth, NH: Heinemann Educational Books.

Clarke, J. and Newman, J. (1997). The managerial state. Sage. London.

Coleman, J. (1988). Social capital in the creation of human capital. American Journal of Sociology, Supplement, Vol. 95, pp. 95-120. The University of Chicago, Chicago.

Denhardt R. (1981). Is the shadow of organization. Lawrence, KS. The Regents Press.

Harmon, M. and Mayer, R. (1986). Organizational Theory for Public Administration. Boston: Little, Brown.

Hage, J., and Finsterbusch, K. (1987). Organizational change as a development strategy: Models \& tactics for improving third world organizations. Boulder, CO.:L. Reinner Publishers.

Klein, P. G. (1998). New Institutional Economics, en Edward Elgar and the University of Ghent, Encyclopedia of Law and economics. Edward Elgar and the University of Ghent.

March, J.G. y Olsen, J.P.(1995). Democratic Governance, New York, The Free Press.

Martínez Nogueira, R. (2001). Estado, sociedad civil y gestión pública. Parte I y II, Magazine No. 25, Instituto Internacional de Gobernabilidad, 18 de diciembre del 2001.

Merton, R.K. (1957). The Role Set: Problem in Sociological Theory. British Journal of Sociology, VIII, June: $113 \mathrm{ff}$. 
Moe, R. C. and Gilmour, R. S. (1995). Rediscovering principles of public administration: The neglected principles of public law. Public Administration Review, 55, (2), 135-146.

Nahallel, A. (2000). European Monetary Union's Deficiencies in Credible Commitment against monetary expansion, Cornell International Law Journal, Vol. 33 (2000), 1. P. 273.

ODA, Overseas Development Administration (1993). Good government technical note No. 16, London: ODA.

O'Donnell, G. (1999). Horizontal accountability and new polyarchies, en Schedler, Andreas, et al., The Self-Restraining State: Power and accountability in New Democracies, Lynne Rienner, Boulder and London, págs. 29-52.

Orozco, M. (2001). Democracia y participación ciudadana, Instituto Internacional de Gobernabilidad. Magazine no. 23, 6 de noviembre del 2001.

Pollit, Ch. (1990). Managerialism and the public service. The Anglo-American experience, Cambridge MA, Basil Blackwell.

Portes, A. (1998). Social Capital: Its Origins and Applications in Modern Sociology. Annual Review of Sociology, 24: 1-24.

Portes, A. and Sensenbrenner, J. (1993). Embeddedness and Immigration: Notes on the Social Determinants of Economic Action. The American Journal of Sociology, Vol. 98, No. 6 (May, 1993), pp. 1320-1350. Published by: The University of Chicago Press.

Reichard, S. (1996). Ideology drives health care reforms in Chile. Journal of Public Health Policy 17(1): 83-98.

Sartori, G. (1999). En defensa de la representación política, Claves de razón práctica. P. 91.

UNESCO (1997). Nuestra diversidad creativa, Informe de la Comisión Mundial de Cultura y Desarrollo, México, 1997.

Weber, M. (1982). La política como vocación, en Escritos políticos, Volumen II, Folios Ediciones, México, pp- 308-364.

Weber, M. (1978). Economy and society (G. Roth \& C. Wittich, Eds.). Berkeley: University of California Press.

Weber, M. (1946). Bureaucracy, Oxford Press.

White, O. F., Jr and Mcswain, C. (1990). The Phoenix project. Raising a new image of public administration from the ashes of the past. Administration and Society Vol. 12(19, 3-38. 
Jose G. Vargas-Hernández

Williamson, O. E. (2000). Why law, economics, and organization?, Business and Public Policy Working Paper BPP-81. Institute of Management, Innovation and Organization, University of California, Berkeley.

World Bank (1992). Governance and development. Washignton, D. C..: World Bank.

Submetido em $28 / 05 / 2015$

Aprovado em 10/12/2015

Sobre o autor

Jose G. Vargas-Hernández

Profesor Investigador miembro del Sistema Nacional de Investigadores

Departamento de Mercadotecnia y Negocios Internacionales/Centro Universitario de Ciencias Económico Administrativas. Universidad de Guadalajara. Periférico Norte 799 Edificio G-306, Zapopan, Jalisco C.P. 45100; México. josevargas@cucea.udg.mx 